previously. Usually $P$ vivax is superimposed on $P$ falciparum so that when the patient has apparently recovered $P$ vivax malaria recurs.

This case of double infection with two relapses (recrudescences) of $P$ falciparum malaria after chemotherapy with chloroquine and a relapse of $P$ vivax malaria after the usual dosage of primaquine for radical cure confirms the increasing importance of the problem of drug resistant malaria imported from the tropics into Europe.

1 Rollo IM. Drugs used in the chemotherapy of malaria. In: Gilman AG, Goodman LS, Gilman A, eds. The pharmacological basis of therapeutics. 6th ed. New York Macmillan, 1980:1038-69.

2 Bruce-Chwatt LJ. Essential malariology. 2nd ed. London: Heinemann, 1985 224-5.

3 Alving AS, Johnson CF, Tarlov AR, Brewer GJ, Kellermeyer RW, Carson PE Mitigation of the haemolytic effect of primaquine and enhancement of its action against exoerythrocytic forms of the Chesson strain of Plasmodium vivax by intermittent regimens of drug administration. Bull WHO 1960;22:621-3

4 Peters W. Antimalarial drug resistance: an increasing problem. Br Med Bull 1982;

Bruce-Chwat

Sectog of relapsing malaria: enigma variations. Trans $R$

Accepted 18 March 1985)

Spallanzani Hospital for Infectious Diseases, Unit of Tropical Medicine, USL RM/16, Rome, Italy

LORENZO SAVIOLI, MD, physician in charge of unit

ANNAPAOLA DE FELICI, MD, senior registrar, laboratory

MARIA GRAZIA PAGLIA, BSC, registrar, laboratory

GIUSEPPE VISCO, MD, chief IInd division

Correspondence to: Dr L Savioli, Vicolo del Farinone 24, 00193 Rome, Italy

\section{Increased serum pancreatic enzymes after treatment with methylprednisolone: possible evidence of subclinical pancreatitis}

On the basis of anecdotal clinical evidence and the results of giving steroids to experimental animals it has been claimed that steroids may be associated with acute pancreatic injury. This report provides evidence that the serum concentrations of the three pancreatic enzymes (trypsin, lipase, and amylase) may increase after administration of large intravenous doses of methylprednisolone.

\section{Patients, methods, and results}

Ten patients with progressive endocrine exophthalmos (euthyroid and with normal renal function) were included in this study. Seven had previously been thyrotoxic and been treated with carbimazole or radioactive iodine. Two were currently receiving carbimazole $10 \mathrm{mg}$ daily. One was hypothyroid and receiving a replacement dose of thyroxine $0.1 \mathrm{mg}$ daily. Two had not had any thyroid dysfunction. All were treated with $1 \mathrm{~g}$ methylprednisolone in $500 \mathrm{ml}$ saline intravenously over two hours on three consecutive days.

Blood samples were collected before the administration of methylprednisolone and daily after treatment for several days. In four patients blood samples were also collected at half hour intervals for three hours after the first methylprednisolone infusion. Serum immunoreactive trypsin concentration was measured by radioimmunoassay using a kit (Hoechst) as described previously. ${ }^{1}$ Total and pancreatic amylase and pancreatic lipase concentrations were measured by kits. ${ }^{23}$

In all 10 patients serum immunoreactive trypsin concentrations increased considerably (by $35-109 \%$ ) after administration of methylprednisolone (table) This was paralleled by similar increases in pancreatic amylase and lipase concentrations. Salivary amylase activity in the serum did not alter. Immunoreactive trypsin concentration peaked on days 5-8 after the infusion, the peak occurring on day 5 in five patients. Peaks in pancreatic amylase and lipase concentrations also occurred on days $5-8$. The increase in pancreatic enzymes was still observed on day 10 , though the concentrations then were considerably lower than the peak values. There was a highly significant correlation between immunoreactive trypsin and pancreatic lipase; immunoreactive trypsin and amylase; and pancreatic lipase and amylase $(r=1.74 ; p=0.002)$. No immediate effect of methylprednisolone on pancreatic enzymes was observed.

None of the patients developed clinical features of pancreatitis or parotitis.

\section{Comment}

In all cases but one the increase in pancreatic enzyme concentrations occurred more than two days after infusion and the peak occurred on days 5-8. The absence of an immediate increase after
Effect of intravenous methylprednisolone on serum pancreatic enzyme concentrations

\begin{tabular}{|c|c|c|c|c|c|c|}
\hline \multirow{2}{*}{$\begin{array}{l}\text { Case } \\
\text { No }\end{array}$} & \multirow{2}{*}{$\begin{array}{l}\text { Time of } \\
\text { measurement }\end{array}$} & \multirow{2}{*}{$\begin{array}{c}\text { Immunoreactive } \\
\text { trypsin }(\mu \mathbf{g} / 1)\end{array}$} & \multirow{2}{*}{$\begin{array}{l}\text { Lipase } \\
(\mathrm{U} / 1)\end{array}$} & \multicolumn{3}{|c|}{ Amylase (U/1) } \\
\hline & & & & Total & Pancreatic & Salivary \\
\hline 1 & $\left\{\begin{array}{l}\text { Basal } \\
\text { Peak (day 5) } \\
\text { Day } 10\end{array}\right.$ & $\begin{array}{l}412 \\
857 \\
627\end{array}$ & $\begin{array}{l}253 \\
298 \\
229\end{array}$ & $\begin{array}{l}102 \\
192 \\
150\end{array}$ & $\begin{array}{r}96 \\
174 \\
132\end{array}$ & $\begin{array}{r}6 \\
18 \\
18\end{array}$ \\
\hline 2 & $\left\{\begin{array}{l}\text { Basal } \\
\text { Peak (day 8) } \\
\text { Day } 10\end{array}\right.$ & $\begin{array}{l}344 \\
699 \\
499\end{array}$ & $\begin{array}{r}72 \\
200 \\
180\end{array}$ & $\begin{array}{l}168 \\
300 \\
200\end{array}$ & $\begin{array}{r}78 \\
156 \\
160\end{array}$ & $\begin{array}{r}90 \\
144 \\
140\end{array}$ \\
\hline 3 & $\left\{\begin{array}{l}\text { Basal } \\
\text { Peak (day 8) } \\
\text { Day } 10\end{array}\right.$ & $\begin{array}{l}323 \\
730 \\
499\end{array}$ & $\begin{array}{l}147 \\
286 \\
249\end{array}$ & $\begin{array}{l}138 \\
252 \\
240\end{array}$ & $\begin{array}{l}102 \\
222 \\
216\end{array}$ & $\begin{array}{l}36 \\
30 \\
24\end{array}$ \\
\hline 4 & $\left\{\begin{array}{l}\text { Basal } \\
\text { Peak (day 3) } \\
\text { Day } 10\end{array}\right.$ & $\begin{array}{l}217 \\
930 \\
360\end{array}$ & $\begin{array}{r}89 \\
350 \\
141\end{array}$ & $\begin{array}{r}90 \\
330 \\
162\end{array}$ & $\begin{array}{r}66 \\
306 \\
120\end{array}$ & $\begin{array}{l}24 \\
24 \\
42\end{array}$ \\
\hline 5 & $\left\{\begin{array}{l}\text { Basal } \\
\text { Peak (day 5) } \\
\text { Day 10 }\end{array}\right.$ & $\begin{array}{l}223 \\
342 \\
214\end{array}$ & $\begin{array}{l}81 \\
99 \\
74\end{array}$ & $\begin{array}{l}282 \\
228 \\
222\end{array}$ & $\begin{array}{l}126 \\
168 \\
144\end{array}$ & $\begin{array}{r}156 \\
60 \\
78\end{array}$ \\
\hline 6 & $\left\{\begin{array}{l}\text { Basal } \\
\text { Peak (day 5) } \\
\text { Day } 10\end{array}\right.$ & $\begin{array}{l}239 \\
436 \\
420\end{array}$ & $\begin{array}{r}82 \\
288 \\
235\end{array}$ & $\begin{array}{l}65 \\
50 \\
55\end{array}$ & & \\
\hline 7 & $\left\{\begin{array}{l}\text { Basal } \\
\text { Peak (day } 7) \\
\text { Day } 10\end{array}\right.$ & $\begin{array}{l}340 \\
510 \\
410\end{array}$ & & & & \\
\hline 8 & $\left\{\begin{array}{l}\text { Basal } \\
\text { Peak (day 5) } \\
\text { Day } 10\end{array}\right.$ & $\begin{array}{l}320 \\
580 \\
425\end{array}$ & & & & \\
\hline 9 & $\left\{\begin{array}{l}\text { Basal } \\
\text { Peak (day 6) } \\
\text { Day } 10\end{array}\right.$ & $\begin{array}{l}275 \\
600 \\
433\end{array}$ & & & & \\
\hline 10 & $\left\{\begin{array}{l}\text { Basal } \\
\text { Peak (day 5) } \\
\text { Day } 10\end{array}\right.$ & $\begin{array}{l}410 \\
810 \\
700\end{array}$ & & & & \\
\hline Norm & ranges & $140-400$ & $50-200$ & & $40-150$ & $30-160$ \\
\hline
\end{tabular}

methylprednisolone and the delay before peak pancreatic enzyme concentrations were reached suggest that this effect was due to the cumulative effects of the steroid and not merely an alteration in the secretory pattern of these enzymes.

Increased serum pancreatic enzyme concentrations have previously been found in association with acute damage of the pancreas, as in acute pancreatitis, and with chronic pancreatic damage, as in cystic fibrosis ${ }^{3}$ and $\beta$ thalassaemia with iron overload; and in elderly asymptomatic subjects. ${ }^{4}$ As serum concentrations of immunoreactive trypsin and other pancreatic enzymes do not increase greatly after a meal or the injection of pancreozymin (in contrast with the changes in intraduodenal pancreatic enzyme concentrations), their delayed and persistent increase after methylprednisolone probably reflects an injury of the pancreatic acinar cell or the acinar basement membrane, or both. This increase in immunoreactive trypsin concentration after methylprednisolone contrasts with the inhibition of exocrine pancreatic secretion into the duodenum after much smaller doses of hydrocortisone and adrenocorticotrophic hormone. ${ }^{5}$

We conclude that an increase in serum pancreatic enzyme concentration after a large dose of steroids may indicate subclinical damage of the pancreatic acinar cell. Persistence of such a stimulus, or its presence in combination with another pancreatic toxin like ethanol or with biliary disease, may predispose to clinical pancreatitis. Our data do not clarify the pathogenesis of pancreatitis induced by steroids, but they show a consistent injurious effect of large doses of these drugs on the exocrine pancreas.

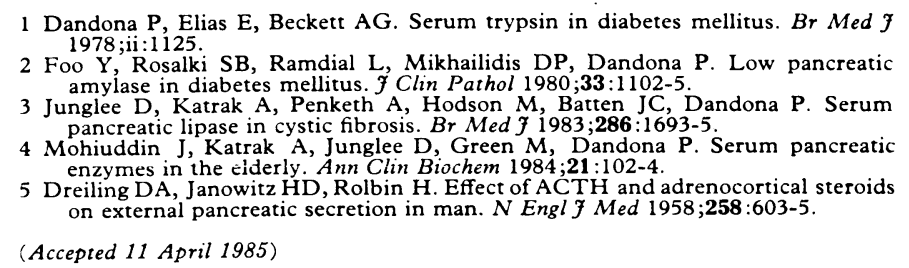

(Accepted 11 April 1985)

Departments of Chemical Pathology and Human Metabolism and Endocrinology, Royal Free Hospital and School of Medicine, London NW3

P DANDONA, DPHIL, MRCP, senior lecturer and director, metabolic unit D JUNGLEE, MSC, medical laboratory scientific officer

A KATRAK, BSC, medical laboratory scientific officer

V FONSECA, MD, MRCP, research fellow

C W H HAVARD, DM, MRCP, consultant physician and endocrinologist

Correspondence to: Dr P Dandona, Metabolic Unit, Department of Clinical Pathology and Human Metabolism, Royal Free Hospital, London NW3 2QG 